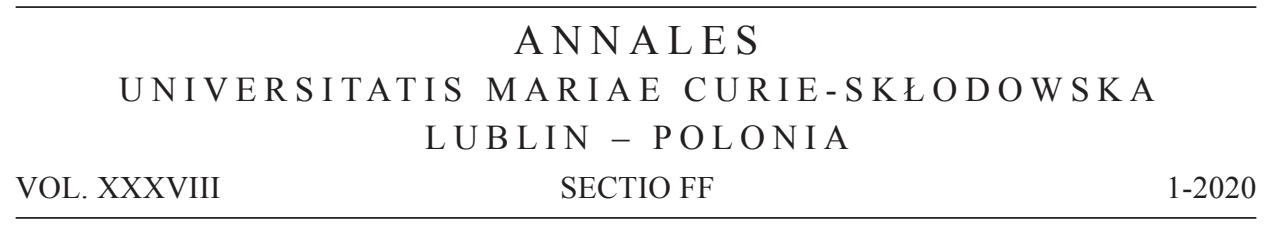

ISSN: 0239-426X • e-ISSN: 2449-853X • Licence: CC-BY 4.0 • DOI: 10.17951/ff.2020.38.1.9-13

\title{
Literature and Reality (Introduction)
}

\author{
Literatura i rzeczywistość (wprowadzenie)
}

The volume you are holding in your hands is devoted to the broadly understood relations between a literary work, journalism and non-fictional reality - the real, tangible world. In his criticism of the hermetic model of poetry, characteristic of Western approaches, which entails creating an opposition between life (reality) and literature, Michał Paweł Markowski warned against separating language from reality, treating both these orders as disproportionate (2009, p. 33). This idea of straying away from creating opposition in order to search for appropriate formulas of description, ${ }^{1}$ methods of research and deciphering activities is what guided the scholars, who prepared the papers compiled in this volume, trying to showcase the complex relations between literary (and - in a broader sense - also cultural) text and reality, as well as their analytical and interpretative consequences

The papers collected in the themed issue of Annales UMCS. Sec. FF offer a variety of methodological perspectives, allowing us to take a look at the eponymous issue in cultural spaces - American, English, Polish, Ukrainian, Belarusian, Russian, Iranian, French, and Surinamese. This diversity and multitude of research directions - consistent with the academic profile of the journal - resulted in an interesting spectrum of issues addressed in the papers, whose temporal range covers

${ }^{1}$ As Tomasz Markiewka (2012, p. 292) wrote: "the result of blurring of the opposition between literature and reality is primarily that instead of looking for the right ways to deal with and describe literature, we start taking more advantage of the manifold opportunities to talk about it" ["rezultat zamazania opozycji między literaturą a rzeczywistością jest przede wszystkim taki, że zamiast poszukiwać właściwych sposobów postępowania z literaturą i opisywania jej samej, zaczniemy bardziej korzystać z wielorakich możliwości mówienia o niej’]. 
both old works (for example, sketches by Michał Kuran, Margarita A. Korzo, Andrii Kuzmenko), as well as the modern ones, as illustrated by papers by Marek Kochanowski, Magdalena Sawa and Sabrina Fatmi.

The issue opens with a paper by Michał Kuran, entitled Old Polish Exhortations (Excitors)-Genesis, Characteristics, and Varieties (Announcement of a Monograph). The study, which announces a future monograph, presents reflections on the literary and functional genres present in Polish literature of the $16^{\text {th }}$ and $17^{\text {th }}$ centuries, whose specificity was based on effectively shaping the reality by using parenthesis.

A sketch by Margarita A. Korzo entitled Reality Invented: How Uniate Josaphat Kuntsevych Supposedly Contributed to the Conversion of Nikon, Patriarch of Moscow. The author focused on the latest hagiographic version of the story written by Skarbek Porfiry Ważyński in order to carry out an analysis aimed at reconstructing the stages of construing reality by means of a narrative, as well as to show how non-literary events inspired creative activities, and how miracles shaped the Orthodox, Uniate and Catholic piety of the time. The author has shown the process of the growth of imagination and its impact on historical reality.

Historical literature was an object of interest for Andrii Kuzmenko. In his paper Ascetic Activity of Fyodor Tumansky in the Context of Popularisation of Ukrainian Studies on the Territory of the Russian Empire in the Late $18^{\text {th }}$ and Early $19^{\text {th }}$ Centuries, he presented the trends pertaining to the popularisation of Ukrainian studies in the western territories of Russia, presented the role of Ukrainian elites in the process of formation of Ukrainian national identity, and also outlined the contribution of the Russian historian Fyodor Tumansky to the formation of Ukrainian culture in Russia, corroborated by source materials. He also showcased how academic and literary activity paved the way for the promotion of Ukrainianness, thus enabling changing reality.

Another article by Beata K. Obsulewicz takes the readers back into the reality of the $19^{\text {th }}$ century, where they can ponder Aleksander Świętochowski's "Damian Capenko." The Struggle with the Legend. It shows the close relationship between the ideas promoted by $19^{\text {th }}$-century positivists and literary discourse on the one hand, and the intertextual relationship between literature and journalism on the other. The presented evidence, gathered using ethnographic, linguistic, press and literary studies, also explains the reasons for the apparent inconsistency of the early Polish work of the "Pope of positivism."

The connection of $19^{\text {th }}$-century literature and philosophy were presented by Urszula Żukowska in her paper entitled A Trial of Materialism. The scholar - who employs arguments from the works by Bolesław Prus and Ignacy Dąbrowski - outlines the way of acceptance of Lucretius' materialistic philosophy in the literature of Polish positivism. 
The multifaceted and complicated relationships between reality, personal experience and memoirs are presented in the paper entitled The Diary of Wactaw Sieroszewski as an Example of the Borderline Between Literature and Historical Policy written by Grażyna Legutko. The analysis of a personal document allows the author to show the impact of historical events on the presented narrative model (heterogeneity of the narrative), as well as on the modification of the memoir model, which turns into a hybrid model over time.

The article by Krzysztof Antoniak Trapped by Femme Fatale in the World without Order: The Simple Art of Hard-Boiled Fiction and Film Noir presents the influence of hard-boiled novels created by Raymond Chandler and Dashiell Hammett in the 1920s and 1930s on the process of shaping the genres of film noir and neo-noir over the next two decades of the $20^{\text {th }}$ century. The author focused on the key issues for both genres - the character of the detective, the urban-labyrinth space, conducive to crime, as well as the femme fatale, who influences the male protagonist.

The paper by Aleksandra Więcek-Gigla "It Was a Mastodon" - Mieczystaw Szczuka's Search for Utilitarian Beauty is devoted to the eponymous figure of a graphic artist and painter active in the interwar period, whose concepts and artistic solutions influenced the shape of visual arts, but also the literature of the period. The author analyses the memoirs, reviews, and artist's own programme statements to reconstruct the biography of the prematurely deceased artist, at the same time pointing to the impact of his proposed solutions on the then Polish literary avant-garde.

The article by Siergiej Kowalow Between Poetics and Reality: Anatol Sys' Early Period takes the reader to the world of Belarusian culture. The author focuses on the early works by Sys, unknown until 2011. The clumsy and imperfect poems testify to the repetitiveness of the young poet, who drew inspiration from the work of Maksim Bahdanovič, only to later develop his own solutions to reflect the existential experience of reality in his texts.

The relationship between literature, culture and reality is presented in the paper Regional Polyethnic Literature of the Belarusian-Polish-Ukrainian Border Region about Life and Creative Values by Maria Zhigalova, who studies the phenomenon of regional multilingual literature. The analysis of imaging in selected works by poets and writers from the Belarusian-Polish borderland (Lubov Kraszewska, Dmitri Kowalow, Włodzimierz Kuczmiński, Zbigniew Fronczek) shows how important a role in shaping creative personalities connected with the borderland is played on the one hand by native tradition and on the other, by the influence of other models (Russian, Polish, and Ukrainian).

As the title of Aleksandra Tryniecka's Bakhtin's Dialogism, Intertextual Theories and Neo-Victorian Fiction indicates, the author is interested in 
multi-faceted textual, genological and cultural relations. The paper puts particular emphasis on the concept proposed by Ryszard Nycz, presenting the relationship between text and text, text and genre, as well as text and reality, in addition to theories by Mikhail Bakhtin, Gérard Genette, Michał Głowiński, and Henryk Markiewicz. Using this tool enables the author to carry out a number of interesting analyses of neo-Victorian literature on the textual, genre and cultural levels.

In her paper Trust and Suspicion: Gabriel Josipovici on Shakespeare and Modernity, Magdalena Sawa took to presenting Josipovici's concepts of contrasting attitudes of trust and suspicion, as well as the way Shakespeare's dramas made them current/relevant. The key proposed by the British critic allows not only for a better understanding of literary texts, but also the nature of human behaviour - in particular at the turn of the epochs, but also in this day and age.

The paper by Damian Olszewski and Krzysztof Pastuszak Two Worlds, One Story. The Comparison of the Storytelling Process in Surinamese Fairy Tales and Improvisational Theatre showcases the cultural similarities between Suriname's oral literature (fairy tales) and improvised theatre performances. The foundation that links the two culturally distinct phenomena is the repetitive nature of the needs of the senders and recipients.

Marek Kochanowski's paper Bialystok and Podlasie in Reportage after 1945. Reality and Stereotypes (a Reconnaissance) takes the readers to the borderline of literature and journalism. The author takes advantage of hermeneutics and the analysis of literary representation in order to propose a review of the stereotypes functioning in contemporary reportage books by Kira Gałczyńska, Zygmunt Kapuściński, Włodzimierz Pawluczuk, Janusz Niczyporowicz, Marcin Kącki, Bartosz Jastrzębski, Jędrzej Morawiecki, Maciej Skawiński, and Piotr Nesterowicz. In these works, Podlasie is presented as a wild land, marked by dirt, rotting mould and destruction, a place of active conflicts, where people still have opportunities to experience primeval miracles, proliferated by folk healers, among others. The studies enable us to conclude that the contemporary clichés in our imagination have had a long-running tradition, dating back to the beginning of the $20^{\text {th }}$ century, and do not seem to have exhausted their potential.

Sabrina Fatmi's article Deterritorializations in the Feminine in the Novel by Chahdortt Djavann or How to Put One's Exile Beyond Borders? concerns contemporary literature from the Francophone circles. Dealing with a novel with clear autobiographical characteristics, the scholar tackles the problem of deterritorialisation (treated as a necessity, a need, as well as a choice), while presenting the relationship between a fictitious character and the author's situation outside literature.

As you can see, the scope of questions tackled by the authors of the submitted papers was quite broad and diverse. This diversity, however, features the 
overarching question, asked both implicitly and explicitly, about the extent, to which the literary and cultural text is built through the experience of the real world, and therefore constitutes a record and a testimony of a certain moment, issue, event, or biographical component relevant to the author.

Monika Gabryś-Stawińska, Constante González Groba

\section{REFERENCES}

Markowski, Michał Paweł. (2009). Życie na miarę literatury: eseje. Kraków: Homini.

Markiewka, Tomasz. (2012). Literatura, rzeczywistość, interpretacja. Teksty Drugie, 1-2, pp. 280-293. 